\title{
Resenha do título inglês "Imagens atuandas. A cultura material de encantamento" (2018) de David Morgan
}

\author{
Helmut Renders
}

\section{Resumo}

Resenha do livro de David Morgan "Images at work. The material culture of enchantment. New York: Oxford University Press, 2018. 224p.”. ISBN: 978-0-19-027211-1 [Tradução do título: "Imagens atuandas. A cultura material de encantamento"].

Review of the title "Images at work. The material culture of enchantment" (2018) by David Morgan

\author{
Abstract \\ Book Review of David Morgan "Images at work. The material culture of enchantment". \\ New York: Oxford University Press, 2018. 224p. ISBN: 978-0-19-027211-1
}

\section{Reseña del título inglés “Imágenes atuandas: La cultura material del encantamento" (2018) de David Morgan}

\section{Resumen}

Reseña del libro de David Morgan. Images at work. The material culture of enchantment. New York: Oxford University Press, 2018”. 224p. ISBN: 978-0-19-027211-1[Tradución del Título: "Imágenes atuandas: La cultura material del encantamento"]

\section{Introdução}

Encantamento é um conceito-chave neste livro e no estudo das religiões. No estudo das religiões, o autor aponta a essência da religião, de tal modo que a sensação do "desencantamento do mundo" foi identificada com o seu desaparecimento. Max Weber se referiu a "Entzanberung (der Welt)", 
que também pode ser traduzido como "desmagificação do (mundo)", o que descreve a perda de uma qualidade poderosa que algo ou alguém pode exercer sobre uma pessoa ${ }^{1}$.

A obra é organizada da seguinte forma:

\section{RECONHECIMENTOS ix}

INTRODUÇÃO 1

1. Crer e fazer crer 23

2. Como imagens atuam 44

3. Encantamento e desencantamento 69

4. A ecologia das imagens 90

5. Ícone e aura 113

6. Oportunidade e a obra do encantamento 138

\section{CONCLUSÕES 168}

\section{NOTAS 179}

\section{BIBLIOGRAFIA SELETA 205}

\section{ÍNDICE 215}

Em sua introdução, Morgan se aproxima do tema pelas experiências do encanto pela música e pela dança, para depois articular a noção humana ancestral dos perigos pelo encantamento [por uma imagem] por intermédio da história de Narciso contada por Ovid (MORGAN, 2019, p. 1-2). Depois ecoa Weber e seu conceito de carisma de lideranças como exemplo positivo e parte para a descrição da intuição do sagrado de Rudolph Otto como mysterium tremendum et fascinans para, então, “... distinguir duas diferentes ênfases do encantamento: encantamento que se concentra num sujeito, capacitando-o a forçar de alguma forma a realidade para acomodar o seu desejo; e encanto que emana do poder de um objeto ou sujeito sobre alguém". Ele afirma seu interesse nas duas formas (MORGAN, 2019, pp. 3-4) e conclua: "Todo encantamento opera como reconhecimento do poder dentro de coisas" (MORGAN, 2019, p. 7) para depois especificar que "Nesse livro

Enquanto se trata de uma mudança de percepção ou perspectiva da pessoa em relação à religião (ao mundo ou a outra pessoa), usar-se-ia Entäuschung, literalmente, "desengano", traduzido por "decepção". 
Resenha do título inglês "Imagens atuandas. 579 A cultura material de encantamento" (2018) de David Morgan

se argumenta que encantamento é algo preservativo nas interações humanas cotidianas com coisas não humanas e que imagens e formas desempenham um papel fundamental nessa relação" (MORGAN, 2019, p. 10). Mais adiante, esclarece sua visão da diferença entre encantamento e magia:

No reino do encantamento objetos, sonhos, imagens, poesias, a passagens e memórias exercem seu poder sobre nós. Com certeza requer mágica palavras, ações, ritos e, muitas vezes, objetos; entretanto, é o magus, a/o feiticeira/o, ou sacerdotes ou a sacerdotisa, o/a shamã quem continua sendo agente primário. (MORGAN, 2019, p. 12).

Isso é uma definição interessante que se aproxima, até certo ponto, no campo da teologia, da ideia do ex opere operato ${ }^{2}$.

... encantamento consiste de ambos: do/a encantando/a como daquilo que encanta. Seguindo essa direção, o encantamento é localizado tanto na mente como no mundo. [...] Coisas encantam tanto a mente e o corpo com a mente e o corpo as encantam. Eu demonstro como imagens operam em redes que sua vez permitem eles trabalhem em nós. (MORGAN, 2019, p. 26).

Depois Morgan argumenta que encantamento não necessariamente requer fé a priori, já que muitas vezes é o ritual que leva à fé.

Fé e prática não deveriam ser reduzidas a uma relação igual a relação tipo galinha - ovo, mas, deveriam ser vistos como co-constitutivos. [...] Mesmo no caso que pessoas se dão conta que aquilo que eles adoram foi manufaturado [feito por mãos humanas, o autor], elas ainda respondam a esse artefato como autônomo e vivo. (MORGAN, 2019, p. 26).

O primeiro capítulo, "Crer e fazer crer" (MORGAN, 2018, pp. 2343), parte de uma reflexão de Bunyan e a forma do seu livro O progresso do peregrino. Dessa reflexão ele faz a distinção entre

\footnotetext{
Dizemos "aproximar" enquanto ex opere operato ("pela obra realizada"), melhor, ex opere operato Christi, afirma que sacramentos recebem seu poder da obra de Cristo e isso independe do papel [sacerdotal etc.] ou do ser humano na sua ministração e do seu estado ético. A frase não afirma que objetos são poderosos em si e que artefatos religiosos operam nas pessoas independentemente de sua aprovação ou fé, ou seja, automaticamente. Isso seria [des]classificado como "magia". Além disso é o efeito ex opere operato distinguido de ex opere operantes ("pela ação daquele que opera") que se refere àqueles/as que administram ou celebram os sacramentos. Nesse caso, o efeito sacramental e distinguido das representações materiais e visuais e vinculado com o momento da celebração (e o/a celebrante).
} 
... duas formas de crença [...] o encantamento do fazer $\mathrm{crer}^{3}$ e o encantamento da crença. O exemplo mais comum do primeiro [...] é a suspensão da descrença [...] Podemos resumir [...] O encantamento da crença é uma forma de sentir e agir em que as pessoas tomam algo como certo e duradouro. $\mathrm{O}$ encanto do faz de conta é equivalente ao comportamento de pessoas que agem como se algo fosse verdadeiro sem ser certo e duradouro. Faz-de-conta delicia-se em condição temporária, a crença. (MORGAN, 2018, pp. 27 e 28).

Mais para frente usa para descrever as duas aproximações "encantamento por um artifício e encantamento por um artefato", significado ainda contido nas palavras fake e fact (MORGAN, 2018, p. 28). Entretanto, MORGAN defende que as duas formas de encantamento muitas vezes se misturam, segundo ele, porque as crenças são formatadas pelas práticas religiosas e cita Latour: "a fé não é um estado da mente, mas, o resultado de relacionamentos entre pessoas” (LATOUR apud MORGAN, 2019, p. 30). Assim fecha na página 43 o capítulo com uma conceituação de trabalho ampla:

(...) Precisamos manter ambos os aspectos de encantamento (crença e imaginação) em jogo, se quisermos fazer justiça a vários fenômenos culturais que desejamos reunir sob o termo. Encantamento é um instrumento para a representação bem-sucedida da dinâmica interior [...], a condição imaginativa para o prazer artístico e o pensamento criativo [...] a atribuição de agência a coisas que não são animadas [...] e a atribuição de intencionalidade ou vontade de evento [...]. Finalmente, o encantamento pode ser auto-ilusão, superstição religiosa, erro epistemológico e a indulgência da psicopatologia.

Conforme já mencionamos, parece essa compreensão mais integradora e muito útil, inclusive, em relação ao estudo de diferentes tipos da cultura material e visual religiosa das mais distintas religiões e dos mais diferenciados comportamentos do ser humano em relação a elas.

O segundo capítulo, Como imagens atuam (MORGAN, 2018, pp. 43-68), começa com uma definição funcional da imagem. Primeiro rejeita a redução da imagem a um tipo de informação seja como "signo, símbolo codificado de um significado ou uma mensagem visual" (MORGAN, 2018, p. 43) e se propôs a explorar diversos modelos da agência da imagem. Para isso, primeiro define a imagem. Ele parte de Sócrates e de sua crítica que imagens são cópias e conduzem o ser humano a assumir papéis representados por elas o que

3 "Make believe", fazer crer, eventualmente também, fazer de conta, fingir ou imaginar [com conotação de auto ilusão, se fazer crer]. 
leva à mera aparência. Depois menciona práticas religiosas greco-romanas da devoção de retratos imaginando a presença de divindades e - na igreja - o caso dos mártires e das suas respectivas relíquias. Rejeitadas ou defendidas, assim Morgan argumenta "Os dois lados concordaram [...] que imagens têm poder sobre seus observadores, entretanto, com resultados diferentes" (MORGAN, 2018, p. 47). Outra perspectiva partiu da ideia de

[...] uma conexão empática (com uma imagem, o autor) que seres humanos formam com elas. [...] Empatia foi entendida como uma projeção do sujeito que percebe. [...]. Segundo esse olhar, a empatia é uma faculdade que trata imagens com algo entre o observador humano e o mundo além [...]. Como faculdade projetiva, então, poderia ser dito que a empatia seja um agente primário do encantamento. (MORGAN, 2018, p. 47).

Depois avança para pesquisas que entendem a imagem como agente. Ele introduz Roland Barthes referente à ideia do punctum como algo que aponta da imagem para o seu observador e cria uma complexa mistura entre os dois que envolve "incorporação, sentimentos e pensamentos" (MORGAN, 2018, p. 48). Depois passa por David Freedberg e sua ideia do Poder das imagens, e cita seu questionamento da distinção entre arte fina e imagens. Segue uma menção da antropologia da imagem de Alfred Gell, Arte e agência (1998) e da teoria de Mitchell. "A explicação de agência de Gell também se concentrou em discernir uma rede de atores: [...] artista, índice (objeto de arte), protótipo (modelo) e destinatário (visualizador). Cada um poderia operar como um agente agindo do outro e como um paciente sendo influenciado por eles” (MORGAN, 2018, p. 51). Nessas discussões, MORGAN se posiciona:

Como Gell e Latour, jamais desejo sugerir algo parecido com uma ontologia animista de objetos auto-alimentados. Eu tenho em mente, ao invés disso, uma abordagem que trata imagens como partes de atos materiais do ver que envolvem humanos em redes grandes e estendidas. (MORGAN, 2018, p. 51).

Num próximo passo, Morgan descreve imagens como interfaces com o mundo: "[...] uma imagem é um dispositivo interativo que quando é visto co-criar uma relação com o espectador, cuja consciência é formada pela imagem por entrelaçar estruturas de sentimento, memória e expectativa" (MORGAN, 2018, p. 52). MORGAN (2018, p. 68) conclui: "Imagens exibem as características de algo feito por seres humanos e 
por si mesmo. Como resultado, vemos que eles nos veem. Eles são um produto da cultura e da natureza".

No próximo capítulo III, Encantamento e desencantamento (MORGAN, 2018, pp. 69-89), Morgan trata da "Mecânica das imagens" (MORGAN, 2018, p. 71), de "Uma aproximação conjunta à cultura material" (MORGAN, 2018, pp. 74-78), do Desencantamento e o poder das imagens" (MORGAN, 2018, pp. 78-83) e do Poder das imagens quebradas" (MORGAN, 2018, pp. 83-89).

O quarto capítulo, designado como $A$ ecologia das imagens (MORGAN, 2018, pp. 90-112) trata de diversas formas e seus respectivos ambientes.

Ícone e Aura4 (MORGAN, 2018, pp. 113-137), quinto capítulo, apresenta uma definição mais ampla e interativa de "cultura visual":

Em contraste com o uso ingênuo do termo 'cultura visual', que considere pouco mais do que artefatos visuais não-artísticos, como fotos de notícias, selos, instantâneos ou stills de filmes, eu defino a cultura visual como a rede de conexão organizada por imagens. Dentro dessas teias, alguns ícones são especiais. Conhecemos um ícone quando o vemos por causa da sensação aurática que provoca: olhando para ele, eu estou na presença de algo ou de alguém. (MORGAN, 2018, p. 120).

Em seguida, começa com a descrição de "ícones culturais" e suas caraterísticas da ubiquidade ${ }^{5}$ de não serem privados. Pelo fato que se encontram em todos os lugares, parecem não ser feitos, mas, encontrados ${ }^{6}$. Morgan mais adiante resume:

Encantamento restringe a aleatoriedade ao torná-la uma agente da ação divina ou sobre-humana e, portanto, ajuda a tornar o universo um lugar mais amistoso e simpático para os seres humanos. Do ponto de vista do interesse humano, o universo nem sempre se comporta de maneira racional, justa ou moral, de modo que as pessoas são compelidas a exercer algum controle através do encantamento. (MORGAN, 2019, pp. 163-164).

Ou como Morgan depois ainda destaca: "O encantamento transforma o mundo num lar” (MORGAN, 2019, p. 170).

\footnotetext{
4 O tema já aparece antes no seu livro Protestants and pictures no capítulo The return of the aura (MORGAN, 1999, pp. 339-348).

5 Importante ressaltar que na teologia é um poderoso atributo divino.

6 Mais um clássico atributo de uma intervenção divina, como Morgan também menciona (2019, p. 122), porém falando de ícones gregos.
} 
Finalmente, no sexto e último capítulo, "Oportunidade e a obra do encantamento", Morgan avança na direção do capítulo anterior.

Não estou convencido a considerar as percepções de milagres, aparições ou o reconhecimento de mensagens em eventos aleatórios como nada mais que erros epistemológicos ou meras projeções. Em vez disso, defendo que o encantamento é mais bem entendido como uma forma de que os seres humanos tornarem o universo cooperativo, dobrando-o para combinar com o seu mundo de vida no qual eles imaginam que existam. Eu gostaria de explorar isso focalizando a atenção na cultura material da adivinhação, onde o acaso ou a aleatoriedade é diferentemente compreendido e colocado em prática. (MORGAN, 2019, p. 124).

Olhando a totalidade, podemos resumir, na perspectiva das ciências da religião, que Morgan não foca na essência da religião, seus fenômenos e sua suposta veracidade, mas, na sua função na vida cotidiano das pessoas, sendo elas consideradas tanto os seus e as suas construtores/as como seus/suas beneficiados/as com o resultado que o encanto "ajuda a tornar o universo um lugar mais amistoso e simpático para os seres humanos". Fica em aberto se ele considera este efeito uma auto-ilusão ou algo que simplesmente ocorre entre o ser humano, a cultura visual e aquele que ela representa para esse ser humano. O título, "Imagens atuandas", aponta para as imagens per se, mas, assim a nossa impressão, Morgan apresenta na presente obra uma análise que se abre ao mistério diante dessa interação de tal modo que as intuições nas quais se baseiam as ideias de um ato icônico e da recepção como empatia precisam ser entendidas como complementares e, ultimamente, inseparáveis. ${ }^{7}$ Podemos dizer: o encantamento somente ocorre nessa perspectiva interdependente do processo entre cultura material, cultura visual, artefato religioso e rito e o ser humano. Uma separação cirúrgica e asséptica faz as imagens se calar (ele se torna inacessível ao ser humano) ou o ser humano não as escutar (o que torna o ser humano insensível diante da imagem).

\footnotetext{
No campo da teologia isso lembra um pouco a discussão a respeito da relação entre a revelação divina e a experiência humana. Segundo Moltmann, o ser humano não pode imaginar a revelação divina sem experimentá-la, e não faz sentido falar de uma experiência religiosa sem imaginar como sua base uma revelação divina. Dessa forma, seriam a revelação divina e a experiência religiosa mutuamente condicionadas, inseparáveis e interdependentes. O próprio Morgan usa também o termo teológico "aliança”, para descrever essa relação e seu caráter interdependente: "O ver opera baseado em alianças com as imagens que estabelecem as condições para uma experiência visual significativa" (Morgan, (2005, p. 31).
} 
Talvez fosse útil, acrescer a noção da responsabilidade do ser humano para a sua crença, no sentido, que ele ou ela, na última instância, não deve culpar a imagem pela sua resposta diante dela. Nesse caso, teríamos passado do encanto para uma superstição, uma infantilidade e irresponsabilidade. Vista a obra de Morgan como um todo, representa Images at work. The material culture of enchantment um tipo de síntese, que integra tanto os modelos de recepção (empatia e simpatia, cf. MORGAN, 1998, pp. 59-96 e 2005, pp. 132-155) como formas da piedade visual com a afirmação da existência de um ato icônico (MORGAN, 2014, p. 289).

\section{Referências}

MORGAN, David. "Images at work. The material culture of enchantment. New York: Oxford University Press, 2018. 224p

"The enchantment of art: abstraction and empathy from German Romanticism to Expressionism". In: Journal of the History of Ideas, Pennsylvania, vol. 57, n. 2, p. 17-341 (abr. 1996). Disponível em: URL: http://www.jstor.org/stable/3654101 Acesso em: 10 maio 2017.

. "The look of sympathy: religion, visual culture, and the social life of feeling”. In: Material Religion, vol. 5, n. 2, p. 132-155 (jul. 2005). DOI 10.2752/ 174322009X12448040551567

. "The look of the sacred". In: The Cambridge Companion to Religious Studies. Cambridge: Cambridge University Press, 2014. p. 296-318.

Protestants and pictures: religion, visual culture, and the age of American mass production. Oxford: Oxford University Press, 1999.

The sacred gaze: religious visual culture. Berkeley, Los Angeles, London: University of California Press, 2005

. Visual piety: a history and theory of popular religious images. Berkeley, Los Angeles, London: University of California Press, 1998.

Submetido em: 28-12-2019

Aceito em: 15-8-2020 